Boom juridisch

Postbus 85576

2508 CG Den Haag

T (070) 3307033

E info@bju.nl

l www.boomjuridisch.nl

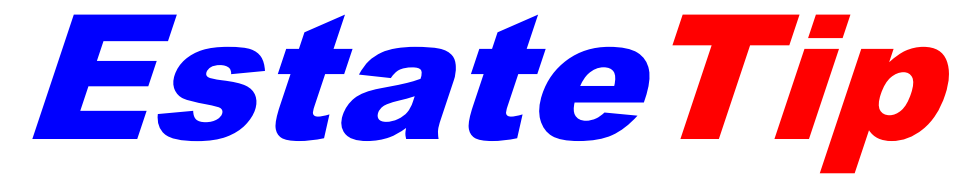

\title{
Postmortaal afstammings- en verzorgingsrecht
}

De familierechtelijke betrekking (art. 1:3 lid $1 \mathrm{BW}$ ) opent de deur tot het erfrecht bij versterf (art. 4:10 lid $3 \mathrm{BW}$ ). Daarmee behoort kennis van het afstammingsrecht tot het basispakket van iedere estate planner. Met dank aan de Rechtbank Gelderland (20 juni 2018, ECLI:NL:RBGEL:2018:2718) kunnen we vandaag een niet alledaagse afstammingsvariant, postmortale inseminatie, combineren met het socialezekerheidsrecht. Verbindende elementen zijn de kosten van verzorging en opvoeding.

Zoals u weet, wordt met enige regelmaat genetisch materiaal van iemand ingevroren. Behalve wetenschappelijke beweegredenen, is een ander motief voor het invriezen het voornemen om dit materiaal op een later moment te gebruiken bij de totstandkoming van een zwangerschap. Dit laatste speelt bijvoorbeeld bij personen die een ingrijpende medische behandeling (moeten) ondergaan. Zo ook in onze casus: man X laat zijn geslachtscellen invriezen. Hij overlijdt, en diens partner, mevrouw $Y$, wil na het overlijden de ingevroren geslachtscellen gebruiken om een zwangerschap tot stand te brengen. De eerste 'horde' die $Y$ dan moet overwinnen, is artikel 7 Embryowet:

'[...] De geslachtscellen worden voorts vernietigd nadat bij degene die ze bewaart, bekend is geworden dat de betrokkene is overleden, tenzij deze uitdrukkelijk schriftelijk toestemming heeft gegeven voor gebruik na zijn overlijden.' (Curs. FH)

Het ligt voor de hand dat in de omstandigheden van onze casus die toestemming is verleend en dat de zwangerschap tot stand kan komen. Vervolgens bevalt $Y$ van dochter $Z$. Voor de verzorging van $Z$ is van belang om te weten wie haar ouder(s) is (zijn). Een ouder is immers verplicht om in het levensonderhoud van diens kind te voorzien (onder meer art. 1:404 lid 1 BW).

Uiteraard is $Y$ als vrouw uit wie het kind is geboren krachtens artikel 1:198 lid 1 aanhef en onder a BW de moeder van $\mathrm{Z}$.

En de overleden $X$ : is/wordt hij vader van kind Z? Hoewel zich dit in de praktijk niet snel zal voordoen, zou $X$ in theorie vader kunnen worden op grond van artikel 1:199 aanhef en onder $b$ BW. Voorwaarde is dan wel dat kind $Z$ wordt geboren binnen 306 dagen nadat het huwelijk (of geregistreerd partnerschap) $X-Y$ door het overlijden van $X$ is ontbonden. In onze casus is het erg onwaarschijnlijk dat $X$ op die wijze vader is geworden. Ook ouderschap door erkenning ligt niet voor de hand. Weliswaar kan op grond van artikel 1:2 BW jo. artikel 1:203 lid $1 \mathrm{BW}$ ook een nog niet geboren kind worden erkend, maar erkenning kan niet - zoals bij postmortale inseminatie het geval is - vóórdat de zwangerschap tot stand is gekomen. 
En omdat, behoudens de uitzondering van artikel 1:200 lid 2 BW laatste volzin, postume adoptie niet mogelijk is, resteert de gerechtelijke vaststelling van het vaderschap als laatste optie om een familierechtelijke betrekking tussen $\mathrm{X}$ en $\mathrm{Z}$ tot stand te brengen.

De gerechtelijke vaststelling van een persoon is mogelijk als die persoon de verwekker is van het kind dan wel als levensgezel van de moeder heeft ingestemd met een daad die de verwekking tot gevolg kan hebben, artikel 1:207 lid 1 aanhef BW.

Het spreekt voor zich dat bij postmortale inseminatie $X$ geen verwekker is. Maar misschien is hij wel een 'instemmend levensgezel'? Uit de toestemming van artikel 7 Embryowet zou best wel eens kunnen worden afgeleid dat $X$ met de postume verwekking heeft ingestemd. En dan zou 'dankzij' de Embryowet het ouderschap van $X$ in zijn hoedanigheid van 'instemmer' wel degelijk gerechtelijk kunnen worden vastgesteld. Dit geschiedde dan ook in onze casus.

Daarmee belanden we bij de vraag hoe in de verzorging van het 'postmortale' kind $Z$ kan worden voorzien. Uiteraard is moeder $Y$ daartoe verplicht, artikel 1:404 BW. Maar kan Z ook - postuum - aankloppen bij vader $X$ ?

Daarmee komen we terecht bij de socialezekerheidskant van de zaak. Rechtbank Gelderland boog zich over de kwestie of moeder $Y$ in aanmerking kwam voor een nabestaandenuitkering als bedoeld in artikel 5 jo. artikel 14 Algemene nabestaandenwet (Anw). Recht op een nabestaandenuitkering heeft, artikel 14 lid 1 aanhef en onder a Anw, de nabestaande van de (overleden) verzekerde die:

'a. een ongehuwd kind heeft, dat jonger is dan 18 jaar en niet tot het huishouden van een ander behoort; of [...]'

Moeder $Y$ voldoet aan dit criterium. Daarnaast is van belang of $Z$ kwalificeert als kind in de zin van artikel 5 lid 1 Anw:

'In deze wet en de daarop berustende bepalingen wordt als kind aangemerkt, een eigen kind, aangehuwd kind of pleegkind in de zin van de Algemene Kinderbijslagwet, dat geboren is voor of op de dag van overlijden van de verzekerde [X].' (Curs. FH)

De Sociale Verzekeringsbank wijst de aanvraag van $Y$ af. Kind $Z$ is pas geboren ná het overlijden van $X$ en is dus geen kind als bedoeld in artikel 5 lid 1 Anw. Moeder $Y$ gaat in beroep bij de Rechtbank Gelderland. Uit de uitspraak blijkt dat $Y$ onder meer stelt dat in de Algemene nabestaandenwet:

'[...] een ongerechtvaardigd onderscheid wordt gemaakt tussen nabestaanden met kinderen die geboren zijn voor of op de dag van overlijden van de verzekerde (of die daarná geboren zijn maar waarvan de vrouw zwanger was op de dag van overlijden van haar echtgenoot) en tussen nabestaanden met kinderen die verwekt zijn na het overlijden van de verzekerde door middel van postmortale inseminatie. Daarmee doet eiseres [X] een beroep op de "open norm" van artikel 14 van het EVRM' (Curs. en toev. FH)

De overwegingen van de rechtbank:

'3.6.3. [...] dat de wetgever voor de vraag of de nabestaande recht heeft op een nabestaandenuitkering bepalend heeft geacht of de nabestaande ten tijde van het overlijden van de verzekerde voldeed aan de voorwaarden om als rechthebbende 
te kunnen worden aangemerkt. Uit die toelichting blijkt namelijk dat de betrokkene pas als nabestaande wordt aangemerkt indien er ten tijde van het overlijden sprake was van een economische afhankelijkheid, tot uitdrukking komend in een financiële band tussen de overledene en de ex-echtgeno(o)t(e). [...]' (Curs. FH)

En:

'3.6.4. [...] De nabestaande die een kind heeft, jonger dan 18 jaar, dat verwekt is door middel van postmortale inseminatie komt niet pas eerst na de verwezenlijking van een verzekerd risico - het overlijden van de verzekerde - (onverwacht) alleen te staan voor de zorg voor hun kind. Op het moment van de keuze om postmortale inseminatie toe te passen staat reeds vast dat de biologische vader is overleden en is er geen sprake van het intreden van een onzekere gebeurtenis en verlies van gedeelde zorg en het niet (hebben) kunnen anticiperen daarop. [...]' (Curs. FH)

De rechtbank concludeert dat voor het onderscheid tussen kinderen geboren vóór en ná het overlijden een redelijke en objectieve rechtvaardiging bestaat, zodat de nabestaandenuitkering terecht is afgewezen.

Vanuit verzorgingsperspectief is de vraag relevant of daarmee ook de deur dicht is voor een beroep van het kind zelf op een wezenuitkering als bedoeld in artikel 26 lid 1 Anw. Ook daarvoor is immers vereist dat de aanvrager $(Z)$ een kind is van de verzekerde. Helaas kwam deze kwestie niet aan bod in de onderhavige uitspraak. De overwegingen van de rechtbank lijken in ieder geval enige ruimte te bieden voor een positieve beslissing.

Tot volgende week!

Mr. F.M.H. Hoens

Radboud Universiteit Nijmegen

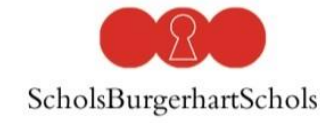

\section{Boomjuridisch}

$\underline{\text { www.scholsburgerhartschols.nl www.boomjuridisch.nl }}$

(C) 2018 Boom juridisch | ScholsBurgerhartSchols

Hoewel de uiterste zorg is besteed aan de inhoud van EstateTip Review aanvaarden de uitgever en de redactie geen aansprakelijkheid voor onvolledigheid of onjuistheid. 